\title{
Measurement of maximal expiratory pressure: effect of holding the lips
}

\author{
J A Fiz, A Carreres, A Rosell, J M Montserrat, J Ruiz, J M Morera
}

\begin{abstract}
Background Minor differences in technique may account for the wide range of published normal values of maximum expiratory and inspiratory pressures. The effects of holding the lips while the subject performed a maximal expiratory pressure manoeuvre were investigated in this study.

Methods Maximum static expiratory pressures (PEmax) obtained with a cylindrical tube by means of lip compression by the subject and technician aided compression were compared in 20 men (mean age 27 years) and 20 women (mean age 28 years).

Results Technician aided lip compression was associated with higher maximum expiratory pressure than compression by the subject in both men (195 $v 110$ $\left.\mathrm{cm} \mathrm{H}_{2} \mathrm{O}\right)$ and women $\left(134 v 80 \mathrm{~cm} \mathrm{H} \mathrm{H}_{2} \mathrm{O}\right)$. Conclusion Compression of the lips and corners of the mouth should be performed by a trained technician for maximum expiratory pressure measurements when a cylindrical mouthpiece is used.
\end{abstract}

\section{(Thorax 1992;47:961-963)}

Measurement of maximum expiratory pressures PEmax under static conditions provides quantitative information about expiratory muscle function and is a useful measure of this in various pulmonary and neuromuscular disorders. ${ }^{1-4}$ Large variations in PEmax are reported in normal subjects. ${ }^{1-5}$ One possible explanation for this variation is that different laboratories use different measuring techniques. ${ }^{13-8}$ Black and Hyatt suggest the use of a large, rigid circular mouthpiece with an adequate seal around the lips but it is often difficult to prevent leakage during expiration. We compared PEmax in a group of normal subjects-firstly, with the subjects holding their lips to the tube and then with help from the technician.

\section{Methods}

Forty healthy non-smokers (20 men), with a mean age of 28 (7) years, weight 63 (13) kg, and height $172(9) \mathrm{cm}$, were studied. None had any symptoms or had had any cardiorespiratory, neurological, hepatic, or endocrine illness. All had been instructed on how to perform maximal inspiratory and expiratory pressure (PImax and Pemax) manoeuvres. None of the subjects was a physiologist and none was familiar with the technique before attending our laboratory.
Forced expiratory volume in 1 second $\left(\mathrm{FEV}_{1}\right)$ and forced vital capacity (FVC) were measured by a spirometer with a pneumotachograph (Gould 2800-IBM System) according to American Thoracic Society guidelines. ${ }^{9}$ A rigid rubber circular tube (internal diameter $2.5 \mathrm{~cm}$ ) with a small hole $(1-2 \mathrm{~mm}$ diameter) to prevent pressure generation by the cheeks when the glottis was closed was used. The lips formed a seal around the surface of the tube. The subject wore a nose clip and sat comfortably upright, with the trunk at an angle of $90^{\circ}$ to the legs.

Pressures were measured with a digital transductor (Sibelmed-163) with a range of 0 to $300 \mathrm{~cm} \mathrm{H}_{2} \mathrm{O}$. PImax was determined from a deep inspiration following a maximal expiration. PEmax was determined at total lung capacity after a deep inspiration following a maximal expiration. Pressures were sustained for more than 1 second.

In the first test the subject maintained the position of the lips around the mouth piece (PEmax S) manually; in the second test, a trained technician compressed the subjects' lips around the cylindrical tube manually (Pemax C). Motivation was sustained by a technician during all manoeuvres. The order of the two tests was random. Measurements were repeated to a maximum of six until there were three acceptable values (that is, values that did not deviate by more than $5 \%$ in each test), after which we abandoned the experiment. ${ }^{10}$ There was approximately 1 minute between manoeuvres and 20 minutes between each test. The maximal values of PEmax and PImax for each test were used in the analysis. Values were compared with normal values, ${ }^{11}$ and between and within group differences were compared by paired and unpaired $t$ test.

Table 1 Mean (SD) anthropometric values and lung function in the men and women studied

\begin{tabular}{|c|c|c|}
\hline & Men & Women \\
\hline Age $(y)$ & $27 \cdot 2 \quad(3.7)$ & $(3 \cdot 3)$ \\
\hline Weight (kg) & $77 \cdot 5(7 \cdot 6)$ & $56 \cdot 1$ \\
\hline Height $(\mathrm{cm})$ & $179.6 \quad(5.4)$ & 164.6 \\
\hline $\mathrm{FEV}_{1}(1)$ & $5 \cdot 2(0.7)$ & $(0 \cdot 4)$ \\
\hline $\mathrm{FEV}_{1}(\%)$ & $112 \cdot 2(12.5)$ & $103 \cdot 8$ \\
\hline FVC (1) & $6.1 \quad(0.9)$ & $3.98 \quad(0.5)$ \\
\hline FVC $(\%)$ & $106.0(11.6)$ & $99.0 \quad(10.6)$ \\
\hline $\mathrm{FEV}_{1} / \mathrm{FVC}(\%)$ & $85 \cdot 3(5 \cdot 7)$ & $85.5 \quad(6.7)$ \\
\hline $\operatorname{PImax}\left(\mathrm{cm} \mathrm{H} \mathrm{H}_{2} \mathrm{O}\right)$ & $112.4(12.4)$ & $86.9(17.0)$ \\
\hline $\operatorname{PImax}(\%)$ & $98.7(9.5)$ & $117.6(10.6)$ \\
\hline
\end{tabular}

$\mathrm{FEV}_{1}=$ forced expiratory volume in 1 second; $\mathrm{FVC}=$ forced vital capacity; PImax maximum inspirational pressure. 
Table 2 Mean (SD) maximum expiratory pressures (PEmax) with (C) and without (S) technician assisted lip compression

\begin{tabular}{|c|c|c|}
\hline \multirow{3}{*}{$\begin{array}{c}\text { PEmax } \mathrm{C}\left(\mathrm{cm} \mathrm{H}_{2} \mathrm{O}\right) \\
(\% \text { predicted })\end{array}$} & Men & Women \\
\hline & $194(26)^{\star}$ & $134(30)^{\star}$ \\
\hline & $125 \quad(15)$ & $88 \quad(20)$ \\
\hline PEmaxS $\left(\mathrm{cm} \mathrm{H}_{2} \mathrm{O}\right)$ & $110 \quad(18)$ & 80 (12) \\
\hline (\% predicted) & $70 \quad(10)$ & $52 \quad(7)$ \\
\hline $\begin{array}{l}\text { PEmaxC-PEmaxS } \\
\left(\mathrm{cm} \mathrm{H}_{2} \mathrm{O}\right)\end{array}$ & $85 \quad(20)$ & $54.5(21)^{\star \star}$ \\
\hline PemaxC-PEmaxS \% & $43.5(07)$ & $40 \cdot 5$ (5) NS \\
\hline PemaxC & & \\
\hline
\end{tabular}

^Significantly different from PEmaxS: $p<0.0001$.

\section{Results}

Mean $\mathrm{FEV}_{1}$, FVC, FEV $/$ FVC, and PImax were within given reference ranges (table 1 ). Pemax S was less than Pemax $\mathrm{C}$ in both men (194 (27); 110 (18) $\left.\mathrm{cm} \mathrm{H}_{2} \mathrm{O} ; \mathrm{p}<0.0001\right)$ and women (134 (30); 80 (12) $\mathrm{cm} \mathrm{H}_{2} \mathrm{O} ; \mathrm{p}<0.0001$ ) (table 2). The difference between PEmaxS and PemaxC was more noticeable in men than in women (85 (20); 54 (21); p < 0.0002) and was correlated with $\mathrm{FEV}_{1}(\mathrm{r}=0.51)$, FVC ( $\mathrm{r}=$ $0.47)$, height $(r=0.49)$, and weight $(r=0.58)$. The difference, expressed as a percentage of PEmax C, was not significant between men $(43.5 \%)$ and women $(40.5 \%)$. No complications from the tests were noted.

\section{Discussion}

This study aimed to determine the effect of the manual compression of the lips on the mouthpiece when PEmax is measured in healthy young adults. Our results show that compression of the lips is an important factor in the measurement of PEmax.

Cook suggested that higher expiratory pressure could be obtained with a tube type mouth piece because it prevented unwanted air leakage. ${ }^{12}$ In 21 healthy volunteers and 40 patients with low, static inspiratory pressure (2 SD below predicted) Koulouris, found higher PEmax values with a tube mouth piece than with a flange type. ${ }^{13}$ The tube had a $4 \mathrm{~cm}$ internal diameter (ID) and was similar to that described by Black and Hyatt, in which the lips projected inside the tube. ${ }^{1}$

Rubenstein $^{14}$ compared three types of mouthpiece: scuba type with three different techniques of lip compression, rigid tube $(2 \cdot 8$ cm ID), and a large bore circular tube $(4 \cdot 1 \mathrm{~cm}$ ID). PEmax functional residual capacity (FRC) values were significantly higher when the patient or technician helped to hold the subject's lips around the mouthpiece. Rubinstein did not, however, find differences in PEmax FRC values between subject and technician aided lip compression. The absence of any differences between the two techniques may be because PEmax was measured at FRC, where Pemax is not maximal. The study group was also small with only eight subjects.

The results of experiments with a tube are contradictory, presumably because some studies have measured PEmax at total lung capacity (TLC) ${ }^{13}$ and others at FRC, ${ }^{14}$ and different sized mouthpieces have been used (table 3 ). In both studies subjects' lips projected inside the tube and the cheeks were not held by the subject or technician. Lower values were obtained with a flanged mouthpiece without lip support than with a tube mouthpiece.

In our study, PEmax was measured at TLC with a rigid rubber tube. The possibility or air leakage was higher than at FRC because the pressures are higher and because there is insufficient compression of the cheeks and corners of the mouth, as reflected in the lower Pemax values when the technician did not hold the lips. Values of PEmax C were similar to those in the study by Koulouris study. ${ }^{13}$

Low values of Pemax S might be caused by antagonistic activity of the diaphragm during static efforts through a mouthpiece, ${ }^{15}$ perhaps influenced by passive compression of the lips. If this were the case, PEmax $C$ would not have been normal when the technician held the lips. We did not carry out diaphragmatic electromyography.

Maximal respiratory pressures can change with lung volume. We assume that volumes were the same in all manoeuvres since they were made after maximal inspiration and the technician rejected any unsatisfactory tests. ${ }^{1}$

We conclude that if the technician helps to hold the lips around the outer surface of the tube leakage can be avoided around the edge of the mouthpiece.

This work was supported by a grant from FISS. We thank J Maggio for translating the paper.

Table 3 Maximum expiratory pressures (PEmax) values $\left(\mathrm{cmH}_{2} \mathrm{O}\right)$ in two previous studies and in the current one

\begin{tabular}{|c|c|c|c|c|c|}
\hline \multirow[b]{3}{*}{$\begin{array}{l}\text { Study } \\
\text { details }\end{array}$} & \multirow[b]{3}{*}{$\begin{array}{l}\text { No of } \\
\text { subjects }\end{array}$} & \multirow[b]{3}{*}{$\begin{array}{l}\text { Age } \\
(y)\end{array}$} & \multicolumn{3}{|l|}{ PEmax } \\
\hline & & & \multirow[b]{2}{*}{$\begin{array}{l}\text { Tube } \\
\text { mouthpiece }\end{array}$} & \multicolumn{2}{|c|}{ Flanged mouthpiece } \\
\hline & & & & Without help & With help \\
\hline \multicolumn{6}{|c|}{$\begin{array}{l}\text { Rubinsten } \text { et } \text { al }^{14} \\
\text { (FRC, } 2.8 \mathrm{ID} \text {, lips inside mouthpiece) }\end{array}$} \\
\hline $\begin{array}{l}\text { Men } \\
\text { Women }\end{array}$ & $\begin{array}{l}12 \\
16\end{array}$ & $\begin{array}{l}37(7) \\
37(7)\end{array}$ & $\begin{array}{r}143(37) \\
99(29)\end{array}$ & $\begin{array}{r}131(26) \\
97(22)\end{array}$ & $\begin{array}{l}161(37) \\
106(28)\end{array}$ \\
\hline $\begin{array}{l}\text { Koulouris } \\
\text { (TLC, } 4 \cdot 0\end{array}$ & & & & & \\
\hline $\begin{array}{l}\text { Men } \\
\text { Women }\end{array}$ & $\begin{array}{l}11 \\
10\end{array}$ & $\begin{array}{l}(23-44) \\
(19-40)\end{array}$ & $\begin{array}{l}190(37) \\
145(44)\end{array}$ & - & $\begin{array}{l}165(39) \\
117(32)\end{array}$ \\
\hline $\begin{array}{l}\text { Fiz JA et al } \\
\text { (TLC, } 2 \cdot 5 \\
\text { Men } \\
\text { Women }\end{array}$ & $\begin{array}{l}20 \\
20\end{array}$ & $\begin{array}{l}27(4) \\
28(3)\end{array}$ & $\begin{array}{l}194(37)^{\star} \\
134(30)^{\star}\end{array}$ & - & - \\
\hline
\end{tabular}

*The technician held the subject's lips. 
1 Black LF, Hyatt RE. Maximal inspiratory pressures: normal values and relationship to age and sex. Am Rev Respir Dis 1969;99:696-702.

2 Arora NS, Rochester DF. Respiratory muscle strength and maximal voluntary ventilation in undernourished patients. Am Rev Respir Dis 1982;126:5-8.

3 Gibson GJ, Pride NB, Newson-Davis J, Loh LC. Pulmonary mechanics in patients with respiratory muscle weakness. Am Rev Respir Dis 1977;115:389-95.

4 Byrd RB, Hyatt RE. Maximal respiratory pressures in chronic obstructive lung disease. Am Rev Respir Dis 1968;98:848-56.

5 Smyth RJ, Chapman KR. Maximal inspiratory and expiratory pressures in adolescents. Normal values. $A m$ Rev Respir Dis 1987;136:1285-98.

6 Leech JA, Ghezzo H, Stevens D, Becklake MR. Respiratory pressures and function in young adults. Am Rev Respir Dis 1983;128:17-23.

7 Wagener JS, Hibbert ME, Landau LI. Maximal respiratory pressures in children. Am Rev Respir Dis 1984;129:873-5.

8 Wilson SH, Cooke NT, Edwards RHT, Spiro SG. Predicted normal values for maximal respiratory pressures in caucasian adults and children. Thorax 1984;39:535-8.
9 Standardization of spirometry 1987 update. Am Rev Respir Dis 1987;136:1285-8.

10 Ferris BJ. Epidemiology standardization project. Am Rev Respir Dis 1978;6 (part 2):7-35.

11 Roca J, Sanchis J, Agusti-Vidal A, Segarva F, Navajas D, Rodriguez-Roisin R, et al. Spirometric reference from a Mediterranean population. Bull Eur Physiopathol Respir 1986;22:217-24.

12 Cook CD, Mead J, Orzalezi NM. Static volume pressure characteristic of the respiratory system during maximum efforts. J Appl Physiol 1964;19:1016-21.

13 Koulouris N, Mulvey DA, Larroche CM, Green M, Moxhan $J$. Comparison of two different mouthpieces for the measurement of $\mathrm{PI}_{\max }$ and $\mathrm{PE}_{\max }$ in normal and weak subjects. Eur Respir J 1988;1:863-7.

14 Rubinstein I, Slutsky AS, Rebuck AS, McClean PA, Boucher R, Szeinberg A, et al. Assessment of maximal expiratory pressure in healthy adults. $J$ Appl Physiol 1988;64 (5):2215-9.

15 Rochester DF, Braun NMT, Lane S. Diaphragmatic energy expenditure in chronic respiratory failure; the effect of assisted ventilation with body respirators. $\mathrm{Am} \mathrm{J} \mathrm{Med}$ 1977;63:223-32.

\section{Adventitia}

\section{A journey to Sakti}

The well ordered life of a pathologist can be disrupted if he falls into the hands of adventurous clinicians. I was never meant by build or inclination to cavort in mountains at high altitude but my long association with Peter Harris determined otherwise. He and Inder Anand became fascinated with the problem of the responses to hypoxia of the pulmonary circulation of the offspring of yaks and cattle in the Himalayas. Yaks are genetically adapted to hypobaric hypoxia and have a low pulmonary arterial pressure. Cattle have to acclimatise to high altitude and develop pulmonary hypertension. They were keen to study the dzo resulting from this union of adapted and acclimatised species and the stol produced by the crossing of dzos and cattle. David Williams and I were invited to travel to the village of Sakti in the Karakorams, in an area of Ladakh at $4000 \mathrm{~m}$ known as Little Tibet, to join these clinicians in their investigation.

It was thought prudent to have a trial run with cardiac catheterisation of two yaks from a herd in England before using the technique on the mountainside. The keeper thought we were deranged even to attempt it and said that, although he fed his yaks every day, he would not risk getting in among them. His sentiments were justified, for the first animal, just 11 months old, suddenly flexed his hindquarters during the procedure and catapulted one of the party through the air to crash into a concrete wall several feet away. In Sakti the yaks were in the charge of the chief herdsman of the village. During cardiac catheterisation they stood motionless under his eagle eye and Peter was able to get excellent tracings. Clearly the best place to study wild and independently minded yaks was in England.

Three attempts to fly to a nearby airstrip at Leh were abandoned by pilots, who would not face the cross winds. Inder organised our party in three small cars to cross the Himalayas, but the winter snows had not melted and the local commander of the army post at the foot of the great mountains would not open the barrier for cars to gain access to the pass. A struggle between clinical science and the Indian Army ensued. As dusk fell a great crowd of Indian drivers with their cars, anxious to get through, assembled around their new found cardiologist leader. In the light of a hundred torches Inder conversed on the telephone with a senior army officer at his headquarters. Each development in the conversation was transmitted to the crowd, which responded periodically with bursts of cheering. The pulmonary circulation triumphed and it was agreed that the pass would be opened at first light on the morrow. We spent the night on the floor of a nearby inn.

Our studies were carried out in a building opposite the Buddhist Tak Tok gompa in Sakti. Each morning, after starting their day with the sounding of trumpets and deep throated horns, the monks in their saffron robes would leave their religious rites and stroll over to see what these alien visitors to their village were up to. The locals were at first deeply suspicious but the ice was broken when a small boy was brave enough to bring his painfully thin pet rabbit to Peter, who took a picture of it with his polaroid camera. This was immediately taken off by the owner and was followed by a remarkable influx of the small boys from the surrounding mountains.

The remote and isolated mountain environment and the Buddhist influence of oppressive quietness and calm amidst the prayer wheels and constantly flapping prayer flags had their effect. Peter became contemplative and given to long, solitary walks in the mountains and the painting of water colours of the animals. Inder, being a Sikh, cast increasingly envious glances at the cattle, regarding them more as owners of a fascinating pulmonary circulation worthy of investigation than as objects of religious reverence. Tension and headaches developed in this ethereal atmosphere and made it difficult to decide whether they were an expression of acute mountain sickness or of unquiet minds. When I found David one morning sitting uncommunicative with his head in his hands I knew the expedition had run its course. Eventually we flew out and I was able to luxuriate in the seat belts that had mysteriously lengthened during my stay in the mountains. I felt no regret at seeing the Karakorams slip away below and I found myself looking forward to returning to the teeming mass of humanity of the fish market in Delhi.-DONALD HEATH 